\title{
Natural Resource Abundance and Economic Performance-A Literature Review
}

\author{
Bimal Chandra Roy, Satyaki Sarkar, Nikhil Ranjan Mandal \\ Department of Architecture, Birla Institute of Technology, Mesra, Ranchi, India \\ Email: bimalcroy@gmail.com
}

Received October $4^{\text {th }}$, 2013; revised November $5^{\text {th }}$, 2013; accepted November $15^{\text {th }}, 2013$

\begin{abstract}
Copyright (c) 2013 Bimal Chandra Roy et al. This is an open access article distributed under the Creative Commons Attribution License, which permits unrestricted use, distribution, and reproduction in any medium, provided the original work is properly cited.
\end{abstract}

\begin{abstract}
It would be a major error to take the decade of the 1970s as the prototype for minerals-based development. The resource curse hypothesis seems anomalous as development economics, since on the surface it has no clear policy implication, but stands as a sad prediction. Minerals are not a curse at all in the sense of inevitability; the curse, where it exists, is self-fulfilling. Needless to say, policies and institutions have to be framed to local circumstances, country by country. But with good intentions and innovative thinking, there is no reason why resource-rich countries need fall prey to the curse.
\end{abstract}

Keywords: Natural Resources; Resource Curse; Institutions; Economic Growth; Dutch Disease

\section{Introduction}

Prior to the late 1980s, it was a common perception that the natural resource abundance was beneficial for economic development of a region. In 1950s most of the economists and geographers were of the opinion that a significant endowment of natural resources facilitates the positive economic growth of any country. According to development theorist Walter Rostow (1961), the natural resource endowments would help developing countries to make transition from underdeveloped to developed as this natural resource abundance will act as the industrial "take-off", just as it had done for countries like Australia, USA and Britain.

Some of the radical economists (Singer, 1950; Prebisch, 1950) stated that the global economy and the nature of the international commodity markets put the developing countries dependent on natural resource export, at a serious disadvantage. But this was a minority view and in general the natural resource abundance was seen as a blessing for developing countries.

After the late 1980s a number of the literature has emerged and challenged this conventional wisdom suggesting that the countries with natural resource abundance increase the chance that the country will experience negative economic growth. This may seem to be a paradox but has been widely accepted by many researchers.

This cycle of "resource curse" started with Sachs and Warner (1995) hereafter referred to as SW who established a negative correlation between the natural resource abundance and the economic growth. SW statistically showed that countries with more natural resources grow slowly compared to resource poor countries. Richard M. Auty (2001) has written "Since the 1960s, the resource poor countries have outperformed the resource rich countries compared by a considerable margin”.

Many other researchers including economists, political scientist and social scientists also agree with SW. But this apparent paradox was a surprising phenomenon and was a topic of curiosity amongst many.

\section{The Resource Curse Theory-Its Origin and Expansion}

Resource curse also known as the "paradox of plenty" is a paradoxical situation in which countries with an abundance of non-renewable resources experience stagnant growth or even negative economic growth. The resource curse occurs as a country begins to focus all of its energies on a single industry, such as mining, and neglects other major sectors. As a result, the nation becomes overly dependent on the price of commodities, and overall gross domestic product becomes extremely volatile. Additionally, government corruption often results when proper resource rights and an income distribution framework is not established in the society, resulting in unfair regulation of the industry.

Richard Auty first introduced the resource curse theory in his 1993 book "Sustaining Development in Mineral Economies: The Resource Curse Thesis". The opening sentences in that book read:

"However, a growing body of evidence suggests that a favourable natural resource endowment may be less beneficial to countries at low-and mid-income levels of development than the conventional wisdom might suppose. Two important pieces of evidence are the developing countries' post-war industrialization efforts and the performance of the mineral-rich developing countries since 1960s. The new evidence suggests that not only many resource-rich developing countries fail to benefit from a favourable endowment; they may actually perform worse than less well-endowed countries. This counter-intuitive outcome is the basis of the resource curse thesis".

Though it seems that for countries endowed with larger quantities of natural resources has an advantage and has to 
grow faster than resource poor countries, but this is not exactly the case. Between 1960 and 1990 the per capita incomes of resource poor countries grew two to three times faster than the per capita income of resource abundant countries, and the gap in the growth rates appears to widen with time (SW, 1999; Auty, 2001a). A large number of papers have been published in recent years supporting the "resource curse" theory and effects that may inhibit growth in resource rich economies.

Figure 1 illustrates for a cross section of countries, over the last four decades. Exports of fuels, ores and metals as a fraction of total merchandise exports appear on the horizontal axis and economic growth on the vertical axis. Noticeably high in growth and low in natural resources are China and some other Asian countries. Noticeably high in natural resources and low in growth are Venezuela and Zambia. The overall relationship on average is slightly negative. The negative correlation is not very strong, masking almost as many resource successes as failures. But it certainly suggests no positive correlation between natural resource wealth and economic growth.

Many African countries such as Angola, Nigeria, Sudan, and the Congo are rich in oil, diamonds, or other minerals, and yet their peoples continue to experience low per capita income and low quality of life. Meanwhile, the East Asian economies Japan, Korea, Taiwan, Singapore and Hong Kong have achieved western-level standards of living despite being rocky islands (or peninsulas) with virtually no exportable natural resources.

Recently the so called resource curse has gained attention largely. Firstly it was established by SW in 1995. Later evidence and further refinement by SW (2001), Gylfason (2001) and Kroneberg (2004) has confirmed the existence of a negative relationship between natural resource abundance and economic growth. The issue, however, remains in dispute.

Some researchers have analyzed the universality of these results to alternative econometric techniques while others have focused on explaining the factors underlying this negative relationship (Rodriguez \& Sachs, 1999; Leite \& Weidman, 2002; Lederman \& Maloney, 2002; Haussmann \& Rigobon 2003; Mehlum et al., 2006; Hodler, 2005).

Figure 2, reproduced from Manzano and Rigobon (2008), illustrates for a cross section of countries. Exports of primary products as a fraction of GDP appear on the horizontal axis and economic growth on the vertical axis. The relationship on average is slightly negative. The negative correlation is not very strong, masking almost as many resource successes as failures. But it certainly suggests no positive correlation between natural resource wealth and economic growth.

Several recent papers, however (Alexeev \& Conrad, 2009; Stijns, 2005; Brunnschweiler, 2006), question the mere existence of the "resource curse" and make it necessary to reconsider the hypotheses about the impact of resource abundance on economic growth.

\section{Impact of Natural Resource Abundance during Different Time Periods}

In the 1950-60 the prime concern was based upon deteriorating terms of trade between the "centre" and "periphery" (Prebisch, 1950; Singer, 1950) with limited economic linkages from primary product export to the rest of the economy (Baldwin, 1966; Hirschman, 1958; Seers, 1964). In 1970 oil shocks on the oil exporting countries was experienced in terms of retarded economic growth of the oil rich countries (Van Wijnber-

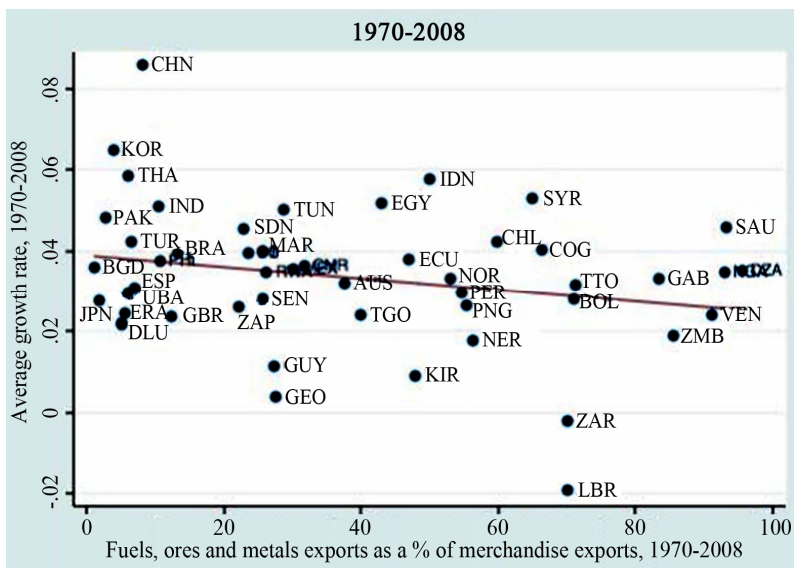

Figure 1.

Statistical relationship between mineral exports and growth; Source: World Development Indicators, World Bank.

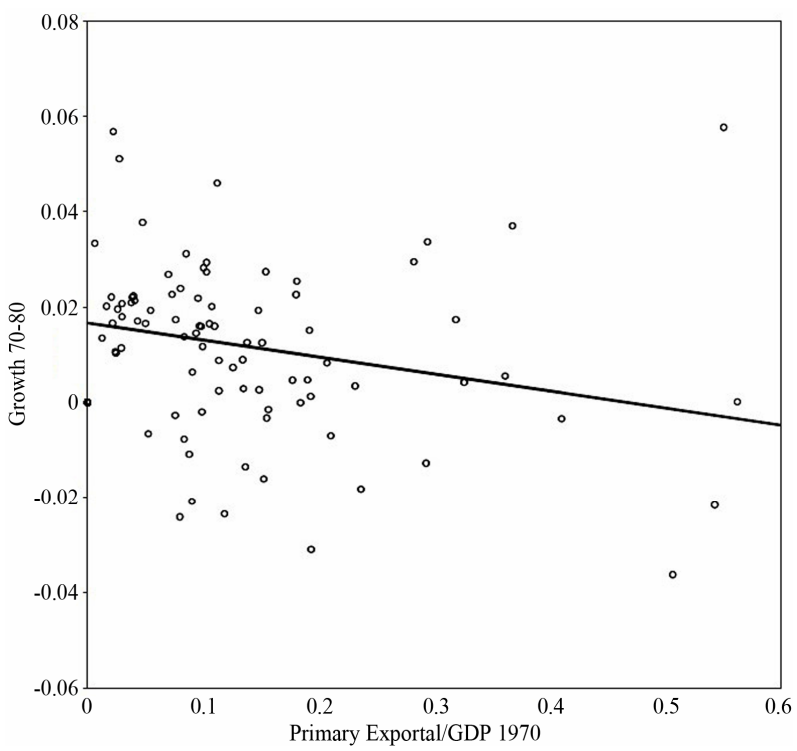

Figure 2.

Natural resource abundance and growth; Source: Manzano and Rigobon (2008).

gen, 1984; Mabro \& Munroe, 1974; Mabro, 1980).

In the 1980's the Dutch disease phenomenon was noticed (Corden \& Neary 1982; Corden \& Max, 1984), in which the discovery of abundant natural gas affected negatively the other sectors particularly the manufacturing sector and there was a slowdown in the economic growth.

In the 1990's it was the impact of the natural resources like oil, gas and minerals on government behaviour or the institutional efficiency and quality that dominated. The impact of institutional quality and efficiency was found to be the subjective factor which when combined with natural resource abundance resulted a positive economic growth.

\section{Types of Natural Resources}

Some recent researches are of the opinion that the pattern of the creation of comparative advantages as a country develops depends not only on whether it is natural resource abundant or 
not, but also on the type of natural resources that abound. For instance, mineral-abundant countries are positioned in a diversification cone with low levels of capital per worker and where they are net importers of all manufacturing goods. In contrast to countries with comparative advantages in forestry and agricultural products, mining countries are the least likely group to change their specialization pattern towards manufacturing goods.

On the basis of geographic surface coverage, the natural resources can be classified into two types-Point Resources and Diffused Resources.

Point resources are extracted from a narrow geographic or economic base and include oil and minerals. The fact that these resources are spatially concentrated implies that they can be protected and controlled at a relatively modest cost. Diffuse resources, on the other hand, are spread thinly in space, and harvested or utilized by agents characterized by horizontal relationships of rough equality and include the agriculture and forests.

Almost all the studies suggest that "point" or concentrated resources result in "worse" institutions, but "diffuse" resources do not. Formal theories for this phenomenon are scarce.

\section{The Resource Curse Models}

\section{Dutch Disease Model}

The phenomenon was first observed in the Netherlands in the 1960s, when large reserves of natural gas in the North Sea were initially exploited where the manufacturing sector declined and suffered general inflation as a result of the booming natural gas sector, which commenced production in 1959. With rising gas exports Holland's exchange rate appreciated against the US dollars and pushed wages up faster than productivity gain in the non-gas sector of the economy. Thus Holland's competitiveness in its other exports, especially manufacturing, was reduced while its demand for domestic non-tradable goods rose, giving rise to inflation and declining savings in investment.

Later in 1970 Dutch Disease experience was seen in oil rich regions.

As SW (1995) elaborates:

"The greater the resources endowments, the higher the demand for non-tradable goods, and the smaller will be the allocation of labour and capital to the manufacturing and agriculture sector. Therefore when natural resources are abundant, tradable production is concentrated in natural resources rather than manufacturing, and capital and labour that otherwise might be employed in manufacturing are pulled into the non-traded goods sector. As a result, when an economy experiences a resource boom (either a terms-of-trade improvement or a resource discovery), the manufacturing sector tends to shrink and the non-traded goods sector tends to expand. The shrinkage of the manufacturing sector is dubbed the 'disease', though there is nothing harmful about the decline in manufacturing if neoclassical, competitive conditions prevail in the economy".

In the Dutch disease model, the economy has three sectors: a tradable natural resource sector, a tradable (non-resource) sector, and a non-traded sector. The greater the natural resource endowment, the higher is the demand for non-tradable goods, and consequently, the smaller will be the allocation of labour and capital to the manufacturing sector.

In Matsuyama’s (1992) model there are two sectors, agricul- ture and manufacturing. Manufacturing is characterized by learning-by-doing, that is, the rate of human capital accumulation in the economy is proportional to total sectoral production, not to the production of an individual firm. Hence the social return to manufacturing employment exceeds the private return. Any force which pushes the economy away from manufacturing and towards agriculture will lower the growth rate by reducing the learning-induced growth of manufacturing. Matsuyama shows that trade liberalization in a land-intensive economy could actually slow economic growth by inducing the economy to shift resources away from manufacturing and towards agriculture.

In Matsuyama's model, the adverse effects of agricultural production arise because the agricultural sector directly employs the factors of production that otherwise would be in manufacturing. Such a framework may be useful for studying labour-intensive production of natural resources, such as in agriculture, but is less relevant for a natural resource sector like oil production, which uses very little labour, and therefore does not directly draw employment from manufacturing. However, it is not difficult to extend Matsuyama's same point in a Hence, lack of savings, heavy dependence on resource revenue and expending them on consumption in the non-tradable goods sector, diversion of labour and capital from agriculture and manufacturing sectors to the booming sector, and higher prices caused by higher wages in the resource sector, with its resultant inflation, all combine to cause the Dutch disease, which consequently affects growth and cause the resource curse.

\section{The Rent-Seeking (Rentier) Model}

The term “rent-seeking” was introduced by Krueger (1974), but the fundamental theory had already been developed by Tullock (1967).

Although originally developed to explain the social welfare losses involved in the establishment of monopolies, tariffs, and subsidies, models of rent-seeking behaviour have been at the forefront of recent attempts to explain the resource curse phenomenon. A common theme of these models is that political institutions conducive to rent-seeking underlie failures of societies to realize benefits from natural resource wealth. Natural resource wealth is a "curse" rather than a benefit to society when property rights are not defined or respected and the wealth becomes a rent-seeking prize (Congleton et al., 2008).

The role of political institutions is central to all rent-seeking models of the resource curse. At the very least, the predictions of these models vary depending on how effective political institutions are at preventing rent-seeking behaviour. Moreover, institutions are themselves endogenous in many of the models and can be negatively affected by a resource windfall. This endogeneity of institutions is a distinguishing aspect of rentseeking models of the resource curse that is not present in mainstream rent-seeking models.

In recent years the literature on the resource curse has taken a turn toward political economy explanations. This turn was motivated by two empirical regularities that are consistent with a political economy story: 1) resource abundance tends to be a curse only when governance institutions are weak initially, and 2) a curse is most likely to plague resources that are found in dense concentrations and are thus easily appropriable. As part of the broad shift toward political economy frameworks, several authors have relied on the idea of rent-seeking to make 
sense of the resource curse phenomenon.

\section{Discussions}

In Wright and Gavin (1990), Gavin also addressed a second issue: "whether resource abundance reflected geological endowment or greater exploitation of geological potential". He argued that "it was mainly the latter". The 1990 paper set the stage for two quite different later papers, David and Wright (1997) and Clay and Wright (2005). Although the focus and methodologies were quite different, each examined the institutions that supported this greater exploitation. Both Wright (1990) and SW (1995) explicitly examined exports. Drawing on data from 97 countries, Sachs and Warner demonstrated that during the 1970s and 1980s "economies with abundant natural resources have tended to grow less rapidly than natural-resource-scarce economies”. The subsequent literature has further documented this regularity and begun to explore its origins. As we will discuss in more detail later, some scholars have found that the empirical regularity is sensitive to how natural resources are measured.

A broad interpretation of Wright (1990) and the later literature on resource curses suggest that they are not necessarily inconsistent. Suppose countries with good institutions were the first to develop their natural resources. The United States and England would be good examples of these early countries. Other countries developed the necessary infrastructure later and began to exploit their natural resources in the early part of the twentieth century. Following World War II markets became less national and more international. Thus the discovery and development of natural resources became less dependent on countryspecific infrastructure. For example, multinational corporations could effectively develop resources in countries even if they had weak institutions. Certainly by the 1970s and 1980s, the countries with the largest as yet undeveloped resources were also the countries with the weakest institutions. Thus, a coherent story can be told that integrates these apparently disparate results.

SW (1997) found limited evidence of natural resources affecting growth through bureaucratic quality. The evidence was stronger for protectionism. In most economies, resource abundance negatively affects the manufacturing sector, which leads to a protectionist response. In a few oil countries, this does not hold. These results raise questions regarding whether the empirical effect and the possible channels would be similar during other periods and with other samples. For example, it is not clearly what one would find if one replicated the Sachs and Warner analysis for the period 1879 to 1928.

This period is when Gavin finds the biggest effect of natural resources on exports. Mehlum, Moene, and Torvik (2006) studied growth over a longer period 1965-1990 using the sample of 87 countries from SW (1997b). They found that the effect of resources on growth is mediated by institutions. They began by examining growth and resources only for countries where resource exports represent more than 10 percent of GDP. These criteria leave them with a data set covering 42 countries. They found that the resource curse only holds for the 21 countries with the worst institutions. In these countries, they argued that rent seeking and production are competing activities. In contrast, in the 21 countries with the best institutions, they argue that rent seeking and production are complementary activities. They then showed that their results hold for the full data set.
Robinson, Torvik, and Verdier (2006) modelled the interaction of natural resource growth with political policies. Based on the model and empirical analysis, they found that institutions were important mediators of the effects of resource booms. Subsequent work by Yang (2008) argued that it was not institutions, but rather policies that affect outcomes. Countries with good institutions can have bad policies and the reverse.

Wright and Czelusta (2004), drawing on a variety of detailed country-level case studies, presented evidence that policies and institutions are critical determinants of how natural resources affect an economy. They began by noting that the measure of resource dependence used by SW (1995) and later scholars was not really a measure of natural resource abundance. It was a measure of export dependency, which may or may not correspond to abundance. They cite the empirical work by Maloney (2002) and Stijns (2005). Brunnschweiler (2008) both surveyed the existing literature and computed new measures of resource endowments. She showed that endowments were positively related to growth.

Contrary to well established perception, so-called "non-renewable" can be progressively extended through exploration, technological progress, and investments in appropriate knowledge. It is suggested that such processes operate within countries as well as for the world as a whole. The countries reviewed are by no means representative, but they are far from homogeneous, and together they disprove the allegation that resource-based development is "cursed". The resource price escalation of the 1970s did indeed constitute an exogenous unanticipated windfall boom from the perspective of many minerals-based economies.

It is obvious in retrospect that those boom times were destined to end, and perhaps one can argue that even then, countries should have been more aware of the transient character of the boom and planned accordingly. Without doubt, many countries made poor use of these onetime gains. There is no guarantee offered against corruption, rent-seeking, and mismanagement of mineral and other natural resources. But the experience of the 1970s stands in marked contrast to the 1990s, when mineral production steadily expanded through purposeful exploration and ongoing advances in the technologies of search, extraction, refining, and utilization; in other words, by a process of learning. It would be a major error to take the decade of the 1970 s as the prototype for minerals-based development.

Gavin and Jesse (1990) then turned to policy. According to Wright and Czelusta (2004), "Non-renewable can be progressively extended through exploration, technological progress, and investments in appropriate knowledge". They argued that countries with policies that have focused on these dimensions have been successful. Similarly bad policies or institutions can lead to bad outcomes. They further found that "Contrary to the paradoxical result that resource abundant countries tend to invite rent seeking and therefore suffer from worse institutions, we find that countries with certain industrial designs may fail to industrialize-and failing to develop significant non-resource sectors may make them dependent on primary sector extraction”.

Although some countries may have experienced more success than others for a variety of reasons, the key issue was that natural resources were a complement to manufacturing. One reason was that high transportation costs and limited functioning of world markets made exporting most natural resources without further processing or value added unattractive. Coun- 
tries without strong institutions and some manufacturing or processing capability simply did not develop their natural resource base. Eventually, particularly after World War II, transportation costs fell and world commodity markets expanded. This made it profitable for many more countries to develop their natural resources, often with the aid of large multinational corporations. But most of the countries with large and relatively untapped natural resource bases were precisely those countries with weak institutions or limited manufacturing or processing capability. To be sure, there were some exceptions. North Sea Oil discoveries in Britain and Norway would certainly be examples. But the vast majority of countries were negatively selected. As Gavin and Jesse (1990) note, this did not necessarily doom them. Some countries began to invest in education, technology, and processing. However, many other countries experienced turmoil, because newfound wealth, volatility in world commodity markets, and weak institutions proved to be an unfortunate combination. Hence we observe resource curse.

The relationship between resource abundance and economic growth is not clear-cut; it could be either positive or negative. It is also possible that resource abundance has no significant impact on economic growth, in the absence of other complementary factors. Thus, there seem to be both growth enhancing and growth retarding factors that can make resource abundance a blessing or a curse.

\section{Shortcomings of the Resource Curse Hypothesis Measurement Issues}

Wright and Czelusta (2004) put the term "resource curse" to critical scrutiny and found that the resource-curse literature pays little attention to the economic character of mineral resources or to the concept of "resource abundance". Most of the researchers have a black box approach. Virtually without exception, these studies equate the export of mineral products with "resource abundance", seen as a simple reflection of an exogenously given geological "endowment”. This synonymy is a matter of implicit assumption rather than analysis or demonstration, generally unquestioned, and all too often unrecognized. On closer scrutiny, each step in this chain of equivalences is questionable. Comparative advantage in resource products is not equivalent to "resource abundance".

Most of the studies related to Resource Curse Hypothesis measure resource intensity in relation to GDP, exports or, in the case of Gylfason, T. and Zoega, G. (2002), total capital stock except Stijns (2001) who measures resource intensity in terms of natural capital per capita.

In almost all the studies the growth is measured using a single, period average annual growth rate, which is modelled in a cross-sectional regression framework. Manzano, O., and Rigobon, R., (2003) use panel data and they derive a number of period average annual growth rates. Further including renewable resources in the measure of natural resource intensity, and particularly, agricultural production is questionable as it is of diffuse resources in nature. Interestingly, Alicia N. Rambaldi (2006) et al. found neither direct nor indirect support for the Resource Curse Hypothesis.

As an economy develops it undergoes structural change, including a decline in the share of primary output in GDP and exports (Chenery, 1960; Chenery \& Syrquin, 1975). With the accumulation of manufactured capital a given stock of natural capital will decline as a proportion of total capital. Countries that were once, by these measures, resource rich and successful in avoiding the resource curse would cease to be classified resource-intensive. It was only because of vast ore and coal deposits that countries like Great Britain and Germany were able to industrialize. By contrast, resource rich countries that have performed badly will continue to appear as resource intensive. SW (2001: 832-833), defend their adherence to a GDP-based measure arguing that currently rich countries that successfully reinvested their natural resource rents did not enjoy the same degree of resource-intensity as the most highly resource-intensive in the mid-to-late 20th century. Even if this assertion is empirically correct, the point of the econometric analysis is to test the relationship between countries' degree of resourceintensity and economic growth. If the measure of the independent variable (resource intensity) is affected by historical changes in the dependent variable (economic growth), circularity and bias are inevitable.

Studies that use more appropriate measures of mineral abundance (such as reserves per capita or the level of natural resource exports per worker) do not find that these variables are negatively associated with growth rates (Maloney, 2002; Stijns, 2003).

\section{Use of Period Averages vs. Panel Data}

The major econometric deficiency of studies using single period mean growth rates as the dependent variable is the information lost as there can only be one observation for each country in the cross-sectional analysis. Using a single, average growth rate from a highly turbulent, two-decade period; mostly, 1970-1990 effectively assumes that the economy has experienced a steady rate of growth (Maloney, 2001; Neumayer, 2004). One exception is Manzano, O., \& Rigbon, R., (2003) who replicate SW's (1995) cross-sectional analysis using panel data. However, they calculate two to four period-averages from the panel. In their model a Fixed Effects estimator is used which removes any time invariant factors such as geography variables from the estimation. Splitting the panel into such large time periods may again fail to capture the effects of expansions and contractions in the resource sector adequately.

When using our measure, evidence of a positive relationship between natural resource abundance and growth is found. We conclude that testing the resource curse hypothesis can be strongly dependent on the definition of resource-intensity and the measurement and modelling of economic growth.

\section{Natural Resource Abundance and the Institutional Quality}

Most of the researches are of the opinion that institutional quality of resource abundant countries play a critical role in the economic growth. For instance, in the Mehlum et al. (2006)' study "Countries rich in natural resources constitute both growth losers and growth winners"; the final result depends on the quality of institutions (p. 16). Mehlum et al. (2006) argue that the resource curse only appears in countries with inferior institutions (p. 3).

Institutional quality doesn't depend on a single indicator. In the empirical literature the term institutions encompass a wide range of indicators, including: 1) institutional quality (the enforcement of property rights); 2) political instability (riots, civil 
wars); 3) distinctiveness of political regimes (elections, constitutions, executive powers); 4) social characteristics (differences in income and in ethnic, religious, and historical background); and 5) social capital (the extent of civic activity and organizations).

Economists often rely on one or several of these types of indicators to capture the features of institutions, although each one has a different impact on growth. However, the largest part of studies on institutional empirical approach relies on the importance of creating an institutional environment that is generally supportive of markets (e.g., protection of property rights and enforcement of contracts).

But in quantitative work on the resource curse hypothesis, the institutional channel has seldom been verified with much success, although it has frequently been mentioned as an important potential cause of the curse. Institutional quality is often simply controlled for by using a measure of corruption (e.g., Papyrakis \& Gerlagh, 2004; Sachs \& Warner, 1995a). There are some notable exceptions: Bulte, Damania, and Deacon (2005) find that natural resource abundance, and especially mineral resources, has an ambiguous direct effect on several measures of human development, and a slightly negative indirect effect via two measures of institutional quality i.e. the rule of law and governance efficiency.

From a more qualitative angle, historians, political scientists, and economists generally agree that the presence of abundant natural resources (especially minerals) leads to rent seeking behaviour and corruption, thereby decreasing the quality of government, which in turn negatively affects economic performance (e.g., Auty, 2001; Isham et al., 2005; Leite \& Weidmann, 1999; Norman, 2009). Robinson et al. (2006) develop a political economy model which shows that the impact of a "resource boom" crucially depends on the quality of the political institutions.

Countries with worse-quality institutions are more likely to suffer from a resource curse. There is also evidence that natural resource abundance considerably increases the potential of violent civil conflict (Collier \& Hoeffler, 2005). Empirically, rent-seeking due to natural resources has been shown to be nonlinear, both with respect to income and the total amount of resources in a country. In his cross-country study, Ross (2001) finds that the negative resource effects of mineral abundance on institutions decline with increasing income levels and with greater past mineral exports. And in their case study of Nigeria, Sala-i-Martin and Subramaniam (2003: p. 10) describe how "oil corrupts and excess oil corrupts more than excessively". They stress that the natural resource curse only holds for mineraland particularly oil abundance, and not agricultural products and food (all measured by their respective export shares).

In a different angle, Atkinson and Hamilton (2003) show that natural resource abundance may have negative effects on development when weak institutions allow resource profits to be spent in government consumption rather than investment, especially in countries with low levels of genuine saving. Stijns (2005) contends that there are both positive and negative channels through which natural resource abundance affects economic growth: he finds that land abundance tends to have negative effects on all determinants of growth, including different measures of institutional quality, while the effects of mineral abundance are less clear-cut. He concludes that "learning processes" are the crucial element in determining the direction of influence of resource wealth on growth, that is, how countries exploit and develop their resources.

From the literature, it emerges that the growth and development effects of natural resource abundance are rather ambiguous when institutional quality is included in the analysis: there may in fact only be a curse when natural resource wealth occurs together with low-quality institutions. The most important institutional aspects in this context appear to be the rule of law and corruption, and the competence of the state and particularly the bureaucracy aspects which are in fact connected.

\section{The Policy Lessons}

A proper policy may help in reducing the curse effect or convert the curse into blessings. Two questions are of great importance, what policy has been followed to help the usual suspect of curse to be enjoyed as blessings. There can't be “one policy fits all” as the countries vary in sizes, types of natural resources, Human Development Index, political, economic and social conditions. However there may be some commonalities and in all cases the fiscal prudent is of great importance. One dimension is the allocation of the revenue generated meticulously for a long time gain. It may be the technology sector or learning sector first, then the physical infrastructure development.

Second one is how this revenue generated is utilised internally for the economic growth of the region. It should be spent on the productive activities. Most of the money may trickle down into private sectors. This may be beneficial for boosting savings and investments. Even if this trickling down of revenue is driven by rent seeking or corruption and this money is invested domestically, may help up to a certain extent for economic growth even if does a little for distribution of income. The problem begins when rent and fruit of corruption accumulate to the bureaucrats and politicians who try to either consume this domestically or deposit in their overseas accounts.

\section{Conclusion}

The resource curse is a phenomenon that occurs at a broader scale than just economic growth-countries that rely on point resources tend to perform worse across a spectrum of criteria. This reinforces a conclusion that others have reached: institutional reform may well be a necessary condition for countries to develop. Finally, if the effects of GDP per capita and governance are accounted for both point and diffuse resource abundance typically have no significant impact (or only a weakened impact) on development.

The experiences of these countries suggest that the resource curse phenomenon is neither universal nor inevitable. Whether resource abundance is a curse or blessing, it appears to hinge on host country circumstances and on the particular resource involved. Still, the notion that having more of any natural resource could be disadvantageous in any circumstance is sufficiently counter-intuitive to merit serious study.

It would be a major error to take the decade of the 1970s as the prototype for minerals-based development. The resource curse hypothesis seems anomalous as development economics, since on the surface it has no clear policy implication, but stands as a sad prediction: countries having rich natural resource endowments have poor growth prospects. Minerals themselves are not to blame for problems of rent seeking and corruption. Instead, it is largely the manner in which policy makers and businesses view minerals that determines the out- 
come. If minerals are conceived as fixed stocks, and mineral abundance as a bonus unconnected to past investment, then the problem becomes one of dividing up the reward rather creating more reward. Minerals are not a curse at all in the sense of inevitability; the curse, where it exists, is self-fulfilling.

Needless to say, policies and institutions have to be framed to local circumstances, country by country. But with good intentions and innovative thinking, there is no reason why resource-rich countries need fall prey to the curse.

Future research arguably should be based on other measures of resource abundance. Following SW (1997), most studies measure resource abundance by the share of natural resource exports in GDP (or total exports). This is of course a direct measure of a country's resource export dependence, and as a flow measure it is at best only an imperfect proxy for a country's actual resource stock. Export shares will not be an accurate measure of resource abundance unless there is a consistent and invariant mapping between in situ resource stocks and annual exports of these stocks. One could argue that the generic SW regression merely demonstrates that primary export intensity hampers growth, and dismiss the more far-reaching proposition that resource abundance impedes growth. To demonstrate convincingly that resource abundance is indeed a curse, and that the results now so prominent in the literature are not spurious, future empirical analysis needs to be based on measures of resource stocks.

\section{REFERENCES}

Alexeev, M., \& Conrad, R. (2009). The elusive curse of oil. Review of Economics and Statistics, 91, 586-598. http://dx.doi.org/10.1162/rest.91.3.586

Atkinson, G., \& Hamilton, K. (2003). Savings, growth and the resource curse hypothesis. World Development, 31, 1793-1807.

Auty, R. M. (2001a). Resource abundance and economic development (p. 360). Oxford University Press.

Auty, R. M. (2001). The political economy of growth collapses in mineral economies (p. 180). Mineral and Energy Press.

Baldwin, R. E. (1966). Economic development and export growth: A study of northern rodhesia, 1920-1960. Berkeley: University of California Press.

Brunnschweiler, C., \& Bulte, E. (2008). The resource curve revisited and revised: A tale of Paradoxes and Red Herrings. Journal of Environmental Economics and Management, 55, 248-264. http://dx.doi.org/10.1016/j.jeem.2007.08.004

Rostow, W. W. (1961). The stages of economic growth: A non-communist manifesto. Cambridge: Cambridge University Press.

Brunnschweiler, C. (2006). Cursing the blessings? Natural resource abundance, institutions, and economic growth. ETH Zurich, Institute of Economic Research, CCRS, University of Zurich.

Bulte, E., Damania, R., \& Deacon, T. (2005). Resource intensity, institutions, and development. World Development, 33, 1029-1044.

Chenery, H. B. (1960). Patterns of industrial growth. The American Economic Review, 50, 624-654.

Chenery, H. B., \& Syrquin, M. (1975). Patterns of development 19501970. Oxford: Oxford University Press.

Clay, K., \& Wright, G. (2005). Order without law? Property rights during the California gold rush. Explorations in Economic History, 42, 155-183. http://dx.doi.org/10.1016/j.eeh.2004.05.003

Collier, P., \& Hoeffler, A. (2005). Resource rents, governance, and conflict. Journal of Conflict Resolution, 49, 625-633. http://dx.doi.org/10.1177/0022002705277551

Congleton, R. D., et al. (2008). Forty years of research on rent seeking: An overview. Berlin: Springer.

Corden, W. M. (1984). Booming sector and dutch disease economics: Survey and consolidation. Oxford Economic Papers, 36, 359-380.
Corden, W. M., \& Neary, P. J. (1982). Booming sector and deindustrialization in a small open economy. Economic Journal, 92, 825-848. http://dx.doi.org/10.2307/2232670

David, P. A., \& Wright, G. (1997). The genesis of american resource abundance. Industrial and Corporate Change, 6, 203-245. http://dx.doi.org/10.1093/icc/6.2.203

Gylfason, T. (2001). Natural resources, education and economic development. European Economic Review, 45, 847-859. http://dx.doi.org/10.1016/S0014-2921(01)00127-1

Gylfason, T., \& Zoega, G. (2002). Inequality and economic growth: Do natural resources matter? CESifo Working Paper, No. 712.

Haussmann, R., \& Rigobon, R. (2003). An alternative interpretation of the resource curse. Theory and Policy Implications, NBER Working Paper No. 9424.

Hirschmann, A. O. (1958). The strategy of economic development. New Haven: Yale University Press.

Hodler, R. (2005). The curse of natural resources in fractionalized countries. European Economic Review.

Kreuger, A. (1974). The political economy of the rent seeking society, American Economic Review, 64, 291-303.

Lederman, D., \& Maloney, W. F. (2007a). Natural resources: Neither curse nor destiny. Stanford University Press.

Leite, C., \& Weidman, J. (1999). Does mother nature corrupt? Natural Resources, Corruption, and Economic Growth, Working Paper WP99/85. Washington DC: International Monetary Fund.

Mabro R., \& Monroe E. (1974). Arab wealth from oil: Problems of its investment. International Affairs, Energy and ARAB Economic Development.

Mabro, R. (1980). Oil revenues and the cost of social and economic development. Energy in the Arab world, 1, Kuwait AFESD and OAPEC.

Maloney, W. F. (2002). Missed opportunities: Innovation and resourcebased growth in Latin America. Economia, 3, 111-150

Maloney, W. F. (2001). Innovation and growth in resource rich countries, central bank of chile. Working Paper 148. Santiago de Chile: Central Bank of Chile.

Manzano, O., \& Rigobon, R. (2001). Resource Curse or Debt Overhang? NBER Working Paper No. 8390, National Bureau of Economic Research.

Manzano, O., \& Rigobon, R. (2003). Resource curse or debt overhang? National Bureau of Economic Research. Working Paper Series No. 8390.

Matsuyama, K. (1992). Agricultural productivity, comparative advantage, and economic growth. Journal of Economic Theory, 58, 317334. http://dx.doi.org/10.1016/0022-0531(92)90057-O

Mehlum, H., Karl, M., \& Torvik, R. (2006). Institutions and the resource curse. The Economic Journal, 116, 1-20. http://dx.doi.org/10.1111/j.1468-0297.2006.01045.x

Neumayer, E. (2004). Does the 'Resource Curse' hold for growth in genuine income as well? World Development, 32, 1627-1640. http://dx.doi.org/10.1016/j.worlddev.2004.05.005

Norman, C. (2009). Rule of law and the resource curse: Abundance versus intensity. Environmental and Resource Economics, 43, 183207.

Papyrakis, E., \& Gerlagh, R. (2004). The resource curse hypothesis and its transmission channels. Journal of Comparative Economics, 32, 181-193. http://dx.doi.org/10.1016/j.jce.2003.11.002

Prebisch, R. (1950). The economic development of latin america and its principal problems. New York: Lake Success.

Rambaldi, A. N., Hall, G., \& Brown, R. P. C. (2006). Re-testing the resource curse hypothesis using panel data and an improved measure of resource intensity. International Association of Agricultural Economists Conference, Gold Coast.

Robinson, J. A., Torvik, R., \& Verdier T. (2006). Political foundations of the resource curse. Journal of Development Economics, 79, 447468. http://dx.doi.org/10.1016/j.jdeveco.2006.01.008

Rodriguez, F., \& Sachs, J. D. (1999). Why do resource-abundant economies grow more slowly? Journal of Economic Growth, 4, 277303. http://dx.doi.org/10.1023/A:1009876618968

Ross, M. L. (2001). Does oil hinder democracy? World Politics, 53, 325-361. http://dx.doi.org/10.1353/wp.2001.0011 
Sachs, J. D., \& Warner, A. M. (1995). Natural resource abundance and economic growth, NBER Working Paper 5398. National Bureau of Economic Research, 49.

Sachs, J. D., \& Warner, A. M. (1995b). Natural resource abundance and economic growth. Development Discussion Paper No. 517a. Harvard Institute for International Development.

Sachs, J. D., \& Andrew, W. (1997b). Sources of slow growth in African economies. Journal of African Economies, 6, 335-376. http://dx.doi.org/10.1093/oxfordjournals.jae.a020932

Sachs, J. D., \& Warner, A. M. (1999). The big push, natural resource booms and growth. Journal of Development Economics, 59, 43-76. http://dx.doi.org/10.1016/S0304-3878(99)00005-X

Sachs, J. D., \& Warner, A. M. (2001). Natural resources and economic development: The curse of natural resources. European Economic Review, 45, 827-838.

http://dx.doi.org/10.1016/S0014-2921(01)00125-8

Sala-i-Martin, X., \& Subramaniam, A. (2003). Addressing the natural resource curse: An illustration from Nigeria. NBER Working Paper 9804. National Bureau of Economic Research.

Seers, D. (1964). The mechanism of an open petroleum economy. Social andEconomic Studies, 13, 233-242.

Singer, H. (1950). The distribution of gains between investing and borrowing, American Economic Review, 40, 473-485.

Stijns, J. P. C. (2001). Natural resource abundance and economic growth revisited. Unpublished mimeo, Department of Economics,
Berkeley: University of California.

Stijns, J.-P. C. (2005). Natural resource abundance and economic growth revisited. Northeastern University.

Stijns, J. P. C. (2005). Natural resource abundance and economic growth revisited. Resources Policy, 30, 107-130. http://dx.doi.org/10.1016/j.resourpol.2005.05.001

Stijns, J.-P. (2003). Three essays on natural resource abundance, economic growth and development. Ph.D. Dissertation, Berkeley: University of California.

Tobias, K. (2004). The curse of natural resources in the transition economies. Economics of Transition, 12, 399-426. http://dx.doi.org/10.1111/j.0967-0750.2004.00187.x

Tullock, G. (1967). The welfare costs of tariffs, monopolies, and theft. Western Economic Journal, 5, 224-232.

Van Wijnbergen, S. (1984). The dutch disease: A disease after all? Economic Journal, 94, 41-55. http://dx.doi.org/10.2307/2232214

Wright, G. (1990). The origins of american industrial success, 18791940. American Economic Review, 80, 651-668.

Wright, G., \& Czelusta, J. (2004). Why economies slow: The myth of the resource curse. Challenge, 47, 6-38.

Wright, G. (1990). The origins of American industrial success, 18791940. American Economic Review, 80, 651-668.

Yang, B. H. (2009). Resource Curse: The role of institutions versus policies. Applied Economics Letters, 17, 61-66. 